\title{
La recepción actual de la literatura brasileña en España
}

\author{
Sérgio MASSUCCI CALDERARO \\ Departamento de Filología Española III \\ Universidad Complutense de Madrid \\ calderaro@quo.com.br
}

\section{RESUMEN}

Este estudio parte de la suposición de que, principalmente a partir del año 2008, el público español que consume frecuentemente los medios de comunicación impresos, digitales y electrónicos viene cambiando su percepción acerca de Brasil en lo que respecta al paso de ese país de la clasificación de subdesarrollado a emergente a nivel económico. A partir de ahí, el artículo intenta buscar respuestas que puedan evidenciar eventuales cambios en la recepción de la literatura brasileña en España resultantes de esta nueva imagen de Brasil, abordando para eso desde aspectos numéricosmercadológicos hasta llegar a análisis teóricos que se adentran en el campo del proceso de lectura..

Palabras clave: literatura brasileña, teoría de la recepción, España, economías emergentes

[Recibido, septiembre 2011; aprobado, diciembre 2011]

\section{The current reception of Brazilian literature in Spain}

\begin{abstract}
This research rests on the assumption that, mainly from the year 2008, the Spanish audience that frequently consumes print, digital an electronic media, has been changing its perception of Brazil regarding the rise of this country in the economic classification from underdeveloped to emergent. From that point the article intends to look for answers that may evidence certain changes in the reception of Brazilian literature in Spain as a result of this new image of Brazil, dealing, for that matter, with numerical and marketing aspects to reach theoretical analyses that go into the area of the reading process.
\end{abstract}

Keywords: Brazilian literature, reception theory, Spain, emerging economies 


\section{Introducción}

Antes de nada, queremos empezar este artículo dejando claro que, aunque utilicemos como punto de partida para nuestros planteamientos un hecho económico, el presente estudio se restringe a comentarios acerca de literatura. El paso de Brasil de país económicamente subdesarrollado a emergente -es hoy la sexta mayor economía del mundo- lo miramos desde la perspectiva del sentido común, pero un sentido común, eso sí, atento a los medios de comunicación españoles, principalmente el periodístico. A ello contribuye el hecho de que, entre 2009 y 2011, hayamos trabajado en el sector de prensa de la Embajada de Brasil en Madrid, donde teníamos como rutina la lectura de al menos, los diarios impresos $A B C$, Público, El Mundo y El País, además de la consulta de las versiones electrónicas de periódicos económicos como Cinco Días, Negocio o Expansión -es más, leerlos formaba parte de nuestras obligaciones-. Creemos que este avance económico de Brasil -que, reconocemos, puede ser cuestionado desde distintas líneas críticas, sobre todo la que reclama la justa división de la riqueza generadaes, cada vez más, conocido por el público español que consume con frecuencia los medios de comunicación impresos, digitales o electrónicos. Lo que nos interesará, por lo tanto, no será la búsqueda de orígenes, historia u otros meandros que revelen las razones del crecimiento económico brasileño, sino, dando por hecho que la mirada española hacia Brasil viene cambiando poco a poco respecto al tema económico, procurar percibir posibles alteraciones en la recepción de la literatura brasileña en España ante esta nueva situación.

Dividiremos el estudio en dos partes principales. En la primera, los comentarios tendrán como base sobretodo hechos concretos e incluso numéricos acerca del mercado editorial. Seguidamente, procederemos a un intento de análisis teórico que evidencie posibles alteraciones de recepción del lector hacía la literatura de un país que acaba de cambiar de escalón económico. Para eso utilizaremos algunos conceptos desarrollados por las teorías literarias de la recepción y del efecto estético, como son el horizonte de expectativas o los espacios de indeterminación. Son dos planteamientos muy distintos -el basado en lo práctico-concreto y el basado en lo teórico-literario-, pero que, juntos, esperamos puedan aclarar algo sobre el panorama sugerido por nuestro cuestionamiento inicial.

\section{Números}

Empecemos por lo más obvio y fácilmente rastreable: los números. Nos referimos a datos concretos relativos al mercado editorial español, es decir, veremos de inicio la evolución numérica de títulos de literatura brasileña traducidos y lanzados en España. El corte temporal será de principios de los 1990 hasta la actualidad. ${ }^{1}$ Veamos.

\footnotetext{
${ }^{1}$ Puede considerarse el lanzamiento del "Plano Real" (27.02.94), que atacó con eficacia la inflación, como una fecha-clave para el principio de un nuevo orden económico en Brasil. Pero la fecha decisiva a considerarse es el año 2008: la quiebra de Lehman Brothers es el símbolo del
} 
Históricamente, la divulgación de la literatura brasileña en España ha sido muy esporádica y poco representativa, principalmente al compararla con la de otros países del ámbito europeo o americano. En un ranking hipotético Brasil seguramente iría después de una veintena de países, como Francia, Inglaterra, Alemania, Rusia, Italia, Estados Unidos, Argentina, Chile, Uruguay, Colombia, Cuba y México, entre otros. Esta posición nada honrosa de Brasil puede ser comprensible si pensamos que, en el caso de los países latinoamericanos, existe la facilidad de la cuestión idiomática, y en el caso de los europeos hay la proximidad geográfica y siglos de historia y formación compartidos. ${ }^{2}$ De la lista anterior, quedaría por justificar la presencia de Estados Unidos, y la respuesta que se nos ocurre como más plausible es la de la posición de liderazgo económico de ese país, que acabó reflejándose en una influencia global de sus productos culturales, entre ellos la literatura. Guardadas las debidas proporciones y volviendo a nuestra pregunta inicial, ¿podría experimentar algún tipo de crecimiento la divulgación de la literatura brasileña en España ante el progreso económico de Brasil?

El gráfico siguiente fue elaborado a partir de datos colectado de la página web de la Fundación Cultural Hispano Brasileña. ${ }^{3}$ Se refieren a la evolución de títulos de autores brasileños lanzados en España -ya sean traducciones al castellano, al catalán, al gallego o al eusquera- entre 1990 y 2009.

inicio de la crisis económica global. Los medios españoles difunden ampliamente el hecho de que Latinoamérica parece no resentirse tanto como Europa o EUA de las turbulencias financieras. La base para estas afirmaciones son los números de crecimiento económico presentados por los países latinoamericanos, encabezados por Brasil.

${ }^{2}$ No pondremos en discusión la "calidad" de la literatura de cada país como criterio de divulgación; se trata de un concepto subjetivo e inabarcable, por lo menos en el ámbito de un artículo.

${ }^{3}$ www.fchb.es 


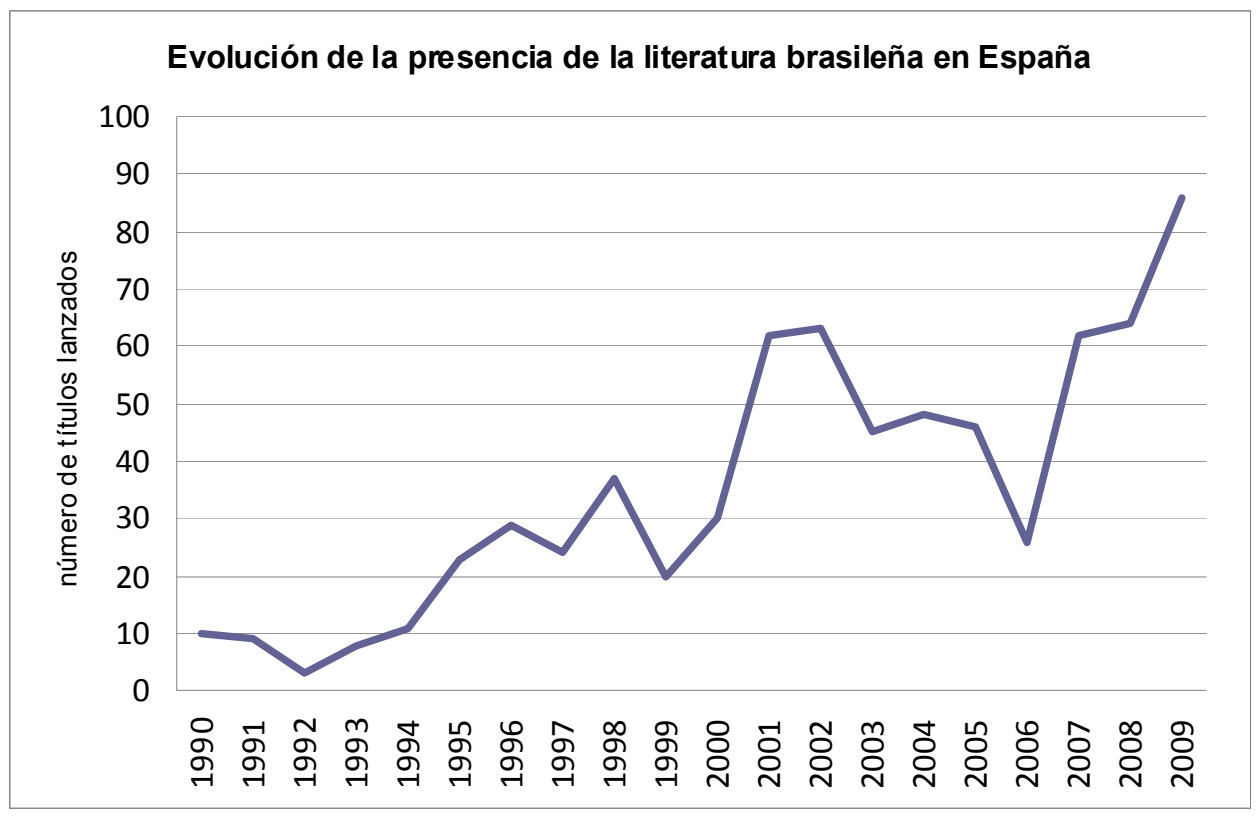

Este gráfico nos da una idea cuantitativa de la situación. Hay un claro crecimiento, aunque la línea presente muchos altibajos. De diez títulos lanzados en 1990 pasamos a 86 títulos en 2009. A partir de principios de los años 2000 parece haber un aumento significativo de interés por la literatura brasileña por parte de las editoriales, tal vez respondiendo a la percepción de crecimiento del interés del público. Pero en 2003 la línea empieza a caer -demostrando que ese aparente aumento de interés suena más a mera casualidad-, para volver a crecer entre los años 2007 y 2008, alcanzando una marca inédita en 2009 y haciéndonos sospechar que a partir de ese momento el interés por la literatura brasileña puede que se mantenga al alza. Contra el posible argumento de que este aumento de lanzamientos de literatura brasileña en España siguiera simplemente como por inercia debido al aumento general de títulos lanzados por el mercado editorial español, sabemos que no es así. En España, según datos de la Federación de Gremios de Editores de España ${ }^{4}$, el sector editorial también viene sufriendo altibajos, pero no coincidentes con los altibajos del gráfico anterior. La gráfica del mercado editorial español iría más bien al contrario que la de títulos brasileños. Entre 2004 y 2005, por ejemplo, mientras cae el número de títulos brasileños lanzados, el número total de ejemplares en general editados en España crece de 310.583.181 a 321.469.155. Ya entre 2008 y 2009 el mercado editorial español experimenta una caída de 367.460 .000 a 329.830 .000 ejemplares editados, pre-

\footnotetext{
${ }^{4}$ www.federacioneditores.org
} 
cisamente cuando el número de títulos brasileños tiene su mayor subida. De todos modos, sería un error sacar conclusiones cualitativas a partir de estos números generales. Es posible, sin embargo, observar que el aumento de títulos brasileños parece coincidir con el principio de la crisis económica mundial y con la consecuente mayor exposición de Brasil en los medios españoles cuando el tema es la propia crisis y las reacciones de los distintos países y regiones del mundo hacia ella. Pero no nos anticipemos. Los números en que nos basamos para elaborar este gráfico se refieren nada más que a la cantidad de títulos traducidos, pero todavía no hemos entrado en detalles que revelen su calidad, es decir, que nos hagan saber qué títulos y qué autores se esconden detrás de las cifras.

\section{Nombres detrás de los números}

Con una mirada más atenta vemos que los escritores Jorge Amado, Clarice Lispector y Machado de Assis son editados en España continuadamente desde los años 70 (la edición más antigua de Jorge Amado en España de la que tenemos noticia es la de Los viejos marineros, de Caralt Editores, de 1968). Pero Amado, Lispector y Machado parecen ser excepciones. Aluísio Azevedo, considerado el fundador y mayor representante de la escuela naturalista en Brasil, no se da a conocer en España antes de finales de 2008, cuando la editorial Antonio Machado lanza El mulato, su primer texto editado en este país. Es de 2008 también el lanzamiento de Recuerdos del escribano Isaías Caminha (Editorial de la Universidad del País Vasco), de Lima Barreto, escritor decisivo en la historia literaria brasileña por su carácter modernizante en el uso de la lengua, en una época en que dominaban en el escenario brasileño los parnasianos. Barreto acabaría siendo una gran influencia para la vanguardia nacional reunida en torno a la Semana de Arte Moderno de 1922. Antes de este año, la única obra de Lima Barreto editada en España había sido Triste fin de Policarpo Cuaresma, en 1997, por la Editorial Allca XX. También otro grande de la literatura brasileña, Murilo Mendes, tuvo que esperar hasta 2008 para dar a conocer a los españoles algunos de sus poemas reunidos en el libro Tiempo español, de la Editorial Almuzara. Sigamos ajustando nuestra lupa a los números y acerquémonos a dos de los más consagrados escritores de la lengua portuguesa en su vertiente brasileña.

El nombre de Oswald de Andrade es conocido en Brasil por todo el que se interese mínimamente en literatura, desde adolecentes de catorce años que le estudian obligatoriamente en la escuela hasta los más mayores que reconocen el nombre del modernista brasileño como sinónimo de vanguardia y búsqueda de identidad nacional. Oswald fue una de las más dinámicas figuras de la Semana de Arte Moderno del 22, que cambió el rumbo del arte brasileño. Ocurre que, en España, nada de ese autor fundamental para la comprensión de la literatura brasileña había sido traducido hasta 2009, cuando la Fundación Juan March reúne muchos de sus textos y lanza el libro titulado Pau Brasil. Es un hecho significativo. Decimos esto por el olvido frecuente de investigadores de lengua española de la vanguardia brasileña, muy poco mencionada en publicaciones sobre litera- 
tura vanguardista latinoamericana o iberoamericana, como si Brasil no formara parte de estos colectivos. De eso nos advierte el estudioso argentino-brasileño Jorge Schwartz, en su imprescindible Vanguardas latino-americanas (Schwartz 2008: 46) ${ }^{5}$ :
Aún los trabajos cuyos títulos incluyen la expresión "América Latina" no hacen mención alguna a las vanguardias brasileñas. Es el caso, por ejemplo, de Fundadores de la Nueva Poesía Latinoamericana, de Saúl Yurkievich, tanto en su edición original como en la segunda, ampliada. Otro estudio de Nelson Osorio T., de ámbito continental, también excluye a Brasil de su re- pertorio. Pasa lo mismo en artículos de Noé Jitrik y de Roberto Fernández Retamar. Gran conocedor de Brasil, el crítico Stefan Baciu sigue esta regla en su conocida antología de la poesía surrealista. Incluso en un texto fun- damental como Los Hijos del Limo, de Octavio Paz (...) no sobra espacio para Brasil. Eso no quiere decir, sin embargo, que no existan trabajos que establezcan puentes. ${ }^{6}$

El hecho de que la Fundación Juan March haya demostrado interés por Oswald de Andrade en el año 2009 puede ser un indicio de que el panorama del cual forma parte la denuncia de Schwartz empieza a cambiar. Si este cambio tiene o no que ver con la alteración de la importancia económica de Brasil en el escenario global, es pronto para concluir. Es algo de lo que sólo podemos desconfiar.

Otra de los indiscutibles nombres literarios brasileños es João Guimarães Rosa. Su osadía, su pericia, su profundidad temática y su experimentalismo lingüístico llevaron a la crítica a compararlo reiteradamente con James Joyce. El público español pudo conocerlo ya en 1967 a través de su obra maestra Gran sertón: veredas, traducida por Ángel Crespo para Seix Barral. En los años 1980, 81 y 82, Seix Barral vuelve a lanzar cuentos de Guimarães Rosa, así como la editorial Alfaguara. Hemos hecho esta introducción porque nos parece oportuno comentar que Gran sertón: veredas ganó hace poco una nueva versión en español por la editorial argentina Adriana Hidalgo, pero en España Rosa sigue siendo un ilustre desconocido incluso en muchos medios literarios y académicos. La última traducción de la principal obra de uno de los mayores prosistas en lengua portuguesa es de Alianza Editorial y data de 1999, es decir, nos acercamos a casi quince años sin que prácticamente se oiga hablar de Rosa por aquí.

Aunque tengamos buenas noticias referentes a recientes lanzamientos de autores brasileños en España, como son los ya comentados casos de Aluizio de Azevedo, Lima Barreto, Murilo Mendes y Oswald de Andrade, parecen no ser suficientes todavía para deducir nada respecto a una eventual mejora de la di-

\footnotetext{
${ }_{6}^{5}$ La traducción del portugués al español es nuestra.

${ }^{6}$ Nos acordamos aquí de Guillermo de Torre y su Historia de las literaturas de vanguardia, que dedica algunas páginas no solamente al Modernismo brasileño de la generación del 22, sino también un capítulo completo a la Poesía Concreta surgida en São Paulo en los años 1950.
} 
vulgación de la literatura brasileña en territorio español a partir del avance del cuadro económico internacional de Brasil. Nos parecen estos lanzamientos, por lo menos de momento, iniciativas aisladas de alguna que otra casa editorial. Para que tengamos un cuadro más completo, tendríamos que seguir buscando información, principalmente en el plano institucional-oficial. Dos iniciativas recientes nos llaman la atención.

\section{Algunas iniciativas de interés}

En enero de 2011 se inaugura en Madrid Ediciones Ambulantes, una editorial dedicada específicamente a la difusión de la literatura brasileña en España. Es un proyecto arriesgado pero que no se basa solamente en el ideal de sus fundadores, sino también en la percepción concreta de que "había un vacío de publicaciones en obras brasileñas en el mercado español". ${ }^{7}$ El primer libro -y único hasta el momento- lanzado por esta editorial es El alma encantadora de las calles, volumen de crónicas de João do Rio, escritor y periodista carioca de principios del siglo XX.

Por último, destacamos una iniciativa del gobierno brasileño: el Ministerio de Cultura, a través de la Fundación Biblioteca Nacional, publicó en 2011 un edicto que da a conocer el "Programa para el apoyo a la traducción y publicación de autores brasileños en el exterior". Esta acción gubernamental tiene el claro objetivo de impulsar la difusión de la literatura brasileña en el exterior, ofreciendo incentivos a las editoriales extranjeras en forma de apoyo financiero para la traducción de obras literarias brasileñas de todos los géneros, así como apoyo para el lanzamiento de reimpresiones de libros ya publicados en el exterior. El programa destina un total de 7.6 millones de dólares a las acciones, que se extienden temporalmente hasta el año 2020. Todavía no podemos cuantificar los resultados de tal iniciativa, pero, desde ya, demuestra que las políticas públicas caminan hacia la intención de una mayor propagación de la literatura brasileña en el exterior, y pensamos que el inédito montante de dinero destinado al programa tiene relación directa con el buen momento económico de Brasil, además de una clara directriz política que considera importantes acciones como estas en el ámbito cultural.

Pero dejemos ahora los números y veamos -con base en conceptos sacados de las teorías literarias de la recepción y del efecto- qué podemos plantearnos respecto a eventuales cambios en la recepción lectora española a partir del avance económico del país de origen de la literatura en cuestión. Cerraremos nuestro foco y pasaremos a mirar ahora al lector, intentando adentrarnos en algunos aspectos que tienen lugar en el proceso de lectura.

\footnotetext{
${ }^{7}$ elEconomista.es (18.07.11):

http://www.eleconomista.es/gestion-empresarial/noticias/3239718/07/11/El-negocio-del-librobrasileno-llega-a-la-biblioteca-espanola.html
} 


\section{Cambios en el proceso de lectura}

Dicen los teóricos de la recepción que el texto impreso no es nada más que uno de los extremos que forman parte de una obra literaria. Para que ese texto cobre vida y entre en funcionamiento hace falta alguien que lo active: el receptor. Por lo tanto, el texto en cuanto objeto físico está sujeto a cambios, los más variables a partir del momento en que se pone en contacto con quien lo recibe, que es cuando alcanza su plenitud. Estudiar una obra literaria, desde ese punto de vista, va más allá de volcarse sobre un autor y sus escritos. El estudio de la obra debe contemplar la supervivencia del texto a lo largo de las distintas épocas en que está sometido a lectura, pues en cada época el texto probablemente se concretará de forma distinta. Además del factor temporal, ganan importancia ahí también factores tan variados como son el social, el etario, el espacial o el cultural. De modo general, podemos decir que el ambiente histórico-social de recepción de una obra influye de manera decisiva en la manera en que cada grupo específico de receptores procederá en la construcción de sentido de tal obra. El texto impreso es siempre solo uno, pero el resultado del texto en contacto con diferentes lectores será siempre más de uno. A título de ejemplo, podemos imaginar que el Gran sertón: veredas, de Guimarães Rosa, será construido de maneras distintas en la conciencia lectora de brasileños, españoles o chinos. La misma obra será construida de manera distinta incluso por dos lectores brasileños, si uno es un adolescente de la ciudad de São Paulo y otro un señor de un pequeño pueblo del sertón de Minas Gerais, escenario de la historia en cuestión. Dicho así, la teoría parece incluso obvia. Vamos a seguir.

No tenemos aquí la pretenciosa intención de explicar la teoría estética de la recepción literaria o la teoría del efecto. Lo que importa tener en mente es que un libro jamás abierto no llega nunca a ser literatura. La literatura, tal como la concebimos, trae consigo en su origen mismo las funciones de comunicación y de cognición, y un libro cerrado, por supuesto, no se comunica con nadie. Es el lector quien establece la comunicación con el escrito, quien construye el significado de un texto literario, haciendo, en fin, que este pueda llamarse literatura. Otra idea que se abandona a partir de la teoría de la recepción es la de la "correcta" construcción de sentido de una obra, como si un libro estuviera a la espera de un lector ideal que supiera interpretar correctamente las instrucciones del texto, como si este libro tuviera una y solamente una lectura posible, la correcta, en detrimento de todas las otras, que serían entonces lecturas equivocadas. Para finalizar este pequeño comentario introductorio, lo que entendemos en suma de estas teorías que abrieron una nueva posibilidad para los estudios literarios a partir de los años 1970, cuando surgieron en Alemania, es que un texto literario, grosso modo, es como un manual de instrucciones de un aparato con innumerables posibilidades de montaje. Es el lector quien, leyendo el manual, construirá a su modo, en su conciencia, influenciado por el ambiente históricosocial en cual está inmerso, su propia obra de arte.

Para que no nos desviemos mucho de la propuesta inicial de este artículo, lo que haremos a continuación será sacar de las teorías de la recepción y del 
efecto solamente algunos conceptos que nos parecen de interés para seguir con el planteamiento que guía este estudio, aplicándolos a nuestro caso específico. El primer de ellos es el concepto de horizonte de expectativas, introducido en la filología por uno de los padres de la teoría de la recepción, el alemán Hans Robert Jauss.

El horizonte de expectativas surge a partir de las condiciones generales de una comunidad homogénea de lectores sobre la cual se proyectará un libro. Estas condiciones influirán en el montaje del texto en la conciencia receptora y son dadas, muchas veces, antes de la llegada de la obra a la futura comunidad lectora. Son ellas las que crean las expectativas de los lectores respecto a una obra o a un conjunto de obras. Según la expectativa que se tenga de un libro o autor específico, este libro o autor será leído de una u otra manera por sus receptores. Es fácil pensar en el caso de una película muy comentada y premiada, con actores famosos, de la cual amigos de nuestra consideración ya nos han hablado muy bien y que, por fin, no nos gusta mucho cuando tenemos la oportunidad de verla. Si no nos hubiesen hablado tan bien de ella, a lo mejor nos habría gustado más. Eso tiene que ver con las expectativas creadas antes de la toma de contacto con la obra y se puede establecer de modo aproximado un paralelismo con el horizonte de expectativas de Jauss. Pero vayamos más allá.

Las expectativas de una comunidad de lectores donde llegará la nueva obra de literatura tienen que ver tanto con el universo literario de los receptores como con su universo extraliterario. Son en realidad dos horizontes que se entremezclan para formar un único panorama. El horizonte de expectativa intraliterario está dado por el gusto literario, las normas y los géneros literarios predominantes en la comunidad receptora en determinada época. Creemos difícil, por ejemplo, que un escritor actual se plantee lanzar un poema épico, ya que este género parece ya no tener cabida en nuestra sociedad. Más aún, nos parece que ningún lector espera o tiene la expectativa de ver en las librerías un larguísimo poema épico de Mario Vargas Llosa o de Carlos Ruiz Zafón, por ejemplo. No estamos diciendo que no tendrían éxito o que no serían buenos o que no serían bien aceptados por la comunidad lectora. Solo que seguramente sorprenderían los lectores. Pero cuando hablamos de horizonte intraliterario nos referimos también a factores todavía más internos, como pueden ser los valores morales divulgados por una novela. Hoy día podemos intuir que de manera general tenemos la expectativa de ver en las historias que leemos una inclinación hacia valores humanitarios, ecológicos o de responsabilidad social, o la denuncia de entes o entidades que no practiquen estos valores. Probablemente nos causaría repulsa o estupefacción, por el total rompimiento de expectativa, deparar con una novela donde hubiese personajes que esclavizasen a otros seres humanos sin que eso fuese considerado de ninguna manera algo malo en la lógica interna de la novela. A lo mejor, una novela con esa característica leída en el siglo XVI no causase la más mínima sorpresa. El juicio de valor sobre una obra está, como hemos visto en líneas muy generales, condicionado por este horizonte de expectativa 
intraliterario, que cambia según el panorama literario en que están insertados los receptores. Queda por comentar algo sobre el horizonte extraliterario.

Igual que el horizonte intraliterario, el extraliterario también está sujeto a alteraciones, pero estas son más de carácter histórico-social y tienen que ver con los intereses, deseos, necesidades y experiencias sociales predominantes en la comunidad receptora. Para un análisis adecuado de la influencia del horizonte de expectativas en la recepción literaria sería necesario un escudriñamiento tan profundo cuanto posible de los panoramas tanto literario como histórico-social de la comunidad receptora a ser analizada. Aquí no tendremos el espacio suficiente ni dedicaremos el tiempo que sería necesario a este gran trabajo, pero nos arriesgaremos a tejer comentarios sobre el ambiente del público al que pretendemos estudiar en este artículo para llegar a su objetivo, que es, recordemos, el de investigar posibles cambios en la recepción de la literatura brasileña en España después del paso de Brasil de país subdesarrollado a económicamente emergente. Creemos que precisamente este punto relativo al horizonte de expectativa extraliterario puede ser un buen campo para que conjeturemos acerca de nuestro tema.

Antes de avanzar, miremos de frente algunas dificultades que se nos presentan. Primera: decir recepción de la literatura brasileña en España supone ya de entrada dos generalizaciones (literatura brasileña; España) que nos llevarían o a sacar conclusiones equivocadas -tomando el todo por alguna de sus parteso entonces -en el caso de querer llevar al pie de la letra estas generalizaciones y afrontarlas- a un trabajo interminable o como mínimo de una extensión espectacular. Bajo el paraguas de literatura brasileña conviven obras diametralmente distintas, así como bajo el paraguas España cohabitan públicos receptores de lo más diverso. Segunda dificultad: sin el artificio de la entrevista personal método que no usaremos- nuestros análisis sobre las expectativas extraliterarias del público receptor tendrán que quedarse más que nunca en el campo de las hipótesis basadas en observaciones y percepciones propias, lo que es siempre un riesgo, tanto en cuanto a la calidad del resultado del estudio como a la probabilidad del surgimiento de críticas en su contra. En cuanto a esta segunda dificultad, asumiremos los riesgos. En cuanto a la primera, tenemos que tomar una actitud que defina mejor nuestros límites de investigación. Para eso tenemos que volver a algunos datos expuestos en la primera parte del artículo. ${ }^{8}$

Si vamos a comparar dos situaciones -la recepción antes y después del avance económico de Brasil- para intentar sacar de ahí alguna posible diferencia, tenemos que fijar límites temporales. Trataremos de pensar, por lo tanto, en recepciones realizadas antes de 2008 y después de 2008, determinando ese año como divisor de aguas en la percepción del público español acerca del creci-

\footnotetext{
${ }^{8}$ Para no huir en demasía de nuestro foco, dejamos de comentar el clásico problema de la traducción, que por sí solo ya es un obstáculo considerable a los estudios de recepción. Leer un texto traducido representa ponerse en contacto con una obra ya recibida y transformada en cierta medida según las condiciones de recepción del traductor, con todas las consecuencias que eso puede implicar.
} 
miento económico de Brasil. 2008 es el año del inicio oficial de la crisis en España y es cuando se empiezan a observar en la prensa escrita española noticias que dan cuenta de la aparente inmunidad de América Latina a los efectos de esa misma crisis, siempre con Brasil a la cabeza del crecimiento económico de esa región. En cuanto a nuestro problema de trabajar con la generalización literatura brasileña, cojamos un ejemplo significativo para que podamos centrar en él nuestros comentarios. Este puede ser Aluísio Azevedo y su libro El mulato, lanzado en España a finales de 2008. Falta delinear con alguna claridad qué queremos decir cuando nos referimos a "público receptor español". Nos centraremos en Madrid, ciudad donde vivimos y convivimos con sus gentes. Y, claro está, hablaremos de un público lector habitual tanto de literatura como del periodismo, un público en su mayor parte formado por licenciados o diplomados, jóvenes y adultos, con interés por temas tanto culturales como políticos, económicos y de toda la realidad global que les afecta. De algún modo, están trazadas las líneas maestras dentro de las cuales nos podremos mover.

Pues bien, volvamos a preguntarnos: ¿qué cambia -si es que algo cambiaen la recepción de un libro como El mulato el hecho de que Brasil, a partir de 2008, empiece a ser percibido como potencia económica emergente por ese público delineado arriba? ¿Qué expectativas podrían tener esos receptores acerca de ese libro antes y después de 2008? Creemos que, si existen cambios, estos serán muy sutiles, por lo menos de momento, y decimos esto por la poca distancia temporal que nos separa del año 2008, insuficiente todavía para que observemos cambios más perceptibles en las expectativas de los receptores. Pero aún así intentemos apurar la vista y mirar precisamente las sutilezas.

Empecemos por esta: la pérdida paulatina del carácter exótico. Hemos sido testimonio en estos años en España de que, por lo menos en el caso de Brasil, su avance político y económico vino acompañado de un visible aumento de la presencia del país en la prensa española. No tenemos los números, pero sabemos a través de fuentes de la propia Embajada de Brasil en Madrid que la cantidad de noticias sobre Brasil o brasileños en los periódicos españoles viene aumentando en gran escala y es hoy incomparable con lo que era hace algunos años. ${ }^{9}$ Exótico es lo lejano, lo extravagante, lo extraño, lo distinto. Cuanto más se sabe sobre algo exótico, cuanta más información frecuente tenemos de ese algo, más cercano y menos exótico acaba pareciéndonos. Lo extravagante nos va pareciendo menos extravagante cada día si, cada día, deparamos una y otra vez con lo extravagante. Aunque siga siendo distinto, ya no nos parece tan extraño. El aumento de noticias acerca de Brasil a la disposición del público español principalmente del público receptor este a que nos referimos- tiene ese efecto de ir poco a poco disminuyendo el carácter exótico del país. Es más: va poco a

\footnotetext{
${ }^{9}$ Uno de los trabajos diarios llevados a cabo por el sector de Prensa de la Embajada de Brasil en Madrid es precisamente el montaje de un "clipping" con todas las noticias de los principales periódicos españoles que tratan sobre el tema Brasil o brasileños, ya sean de política, justicia, salud, economía, cultura o cualquier otro asunto.
} 
poco eliminando estereotipos, lo que tendrá su efecto en las expectativas de los lectores acerca de la literatura brasileña, como iremos viendo.

Imaginamos que la expectativa que se tiene antes de leer una novela de un autor estadounidense es bastante distinta de la expectativa hacia una novela de un autor camboyano, por ejemplo. Mucho de esta diferencia, creemos, reside en el carácter exótico que nos sugeriría el marco literatura camboyana. La expectativa, intuimos, sería la de leer algo distinto de lo que solemos leer. Esperaríamos depararnos probablemente con paisajes, personajes y costumbres distintos, además de poder esperar un tipo de narrativa también distinto, ya sea innovadora o no, pero un modo diferente de contar las cosas. Ahora pensemos: si Camboya empieza a despuntar como potencia económica y a partir de ahí las páginas de los periódicos pasan a dar mucha más atención no solo a la economía de ese país, sino también a su cultura, deporte y política, al cabo de algunos años este lejano país quizás ya no nos parezca tan exótico, y tampoco su literatura. La expectativa hacia la literatura camboyana sería una, por lo tanto, antes de su despunte económico, y otra años después del despunte, siempre que el avance económico se mantuviera y la exposición en los medios también.

Brasil no es Camboya e tal vez no parezca tan exótico como el país asiático a los ojos de los españoles. Pero aún así el paralelismo entre Brasil y el hipotético ejemplo camboyano que acabamos de mencionar puede mantenerse. Además, hoy en día, avanzar económicamente significa caminar hacia la integración con el modo de vida de los prósperos países occidentales, es decir, el éxito económico conlleva una adaptación del país que emerge a los modos de vivir de las mayores potencias occidentales, como EEUU, Inglaterra, Francia o Alemania. Otro ejemplo: a nuestros ojos, Japón no suena tan exótico como pueden sonar Mongolia, Vietnam o la propia Camboya. Suráfrica puede que no nos suene tan exótico como sonarían Botsuana o Namibia. Turquía no nos suena tan exótico como Kazajistán. Se trata, todos, de países vecinos o muy cercanos geográficamente. Sin embargo, los primeros son desarrollados o emergentes y de ellos recibimos noticias frecuentemente, mientras de los otros nada o casi nada se escucha hablar. Los primeros están totalmente integrados o van integrándose poco a poco en el modo de vida "normal", occidental y capitalistamente avanzado. Los otros siguen siendo exóticos.

La expectativa ante la literatura brasileña, nos parece cada vez más claro, está cambiando. El avance económico del país suramericano tiene como resultado la pérdida paulatina del carácter exótico que pudiera tener Brasil, en mayor o menor grado, entre los receptores que nos interesan. Imaginamos que será muy distinta la expectativa de un universitario madrileño de los años 1970 que abría por primera vez un libro de Jorge Amado y la de un universitario madrileño que abra el mismo libro en la actualidad. Los libros de literatura brasileña que actualmente llegan al público español son proyectados ya sobre un horizonte de expectativas cambiado en relación al horizonte de pocos años atrás. Ya no se espera leer literatura exótica de un país lejano. Eso seguramente cambiará algo en la manera en que se leen estas obras. Veamos ahora el resultado de este 
y otros posibles cambios de horizonte de expectativas, aunque sutiles, en el caso específico de la recepción de El mulato, de Aluísio Azevedo, libro elegido para nuestros comentarios.

Cuando tenemos la tarea de analizar la recepción de un libro que se aleja en el tiempo en relación a los receptores (en este caso, cerca de 130 años) y que además fue escrito en otra circunstancia geográfica y social, hay que redoblar la atención. Si consideramos lo que dice el filósofo alemán Hans Georg Gadamer, todo libro surge como respuesta a una pregunta. Gadamer, incluso, utilizaba un concepto llamado "horizonte de preguntas" para designar casi lo mismo que años después Jauss vendría a llamar horizonte de expectativas. Según el concepto de horizonte de preguntas, un texto funciona como contestación a los cuestionamientos previamente formulados por determinada comunidad de lectores ubicada histórica y socialmente. La consecuencia de la distancia temporal, histórica, espacial y social de El mulato en relación al público receptor que entra en nuestro análisis es que la pregunta a qué sirve de contestación el libro ya no existe, o por lo menos no existe tal y como fue formulada por los lectores de la época y lugar de lanzamiento del libro. Eso, por supuesto, cambiaría la recepción en la España actual en relación al receptor brasileño de 1881, año de la primera publicación del libro. Pero lo que nos interesa no es tanto analizar la diferencia de la recepción de Brasil en 1881 y España en 2008, sino buscar eventuales diferencias en la recepción de España en 2008 y de España en los años subsiguientes a 2008, cuando, cada vez más, empieza a difundirse entre el público español delineado el avance económico de Brasil. Este es el foco de nuestro trabajo desde el principio. De todos modos, puede que sea necesario tejer uno que otro comentario acerca de las preguntas que originalmente motivaron la aparición del libro en 1881, para que, a partir de ahí, tengamos una mejor comprensión de la obra y sus posibles recepciones hoy día. Vamos allá.

El horizonte de preguntas surge de las expectativas que conviven en una comunidad. Las personas esperan cosas, esperan respuestas a sus aflicciones generales acerca de la vida -ya sean de foro social, político, existencial etc.- y crean expectativas acerca de lo que vendrá, de lo que les reserva el futuro. Buscan respuestas en los más diversos sitios: en acciones políticas, en actitudes vecinales, en los periódicos, en la tele e incluso en la literatura, que es nuestro caso específico. Las reacciones a estas respuestas pueden variar de la completa frustración (que en casos extremos pueden llevar al odio y a la violencia), cuando las expectativas no se cumplen, al total regocijo, cuando las expectativas se cumplen al cien por cien.

Sabemos que El Mulato -considerado el inaugurador del estilo realistanaturalista en Brasil- surgió en 1881 contestando a preguntas de su época. En este año ya era muy fuerte, e incluso vista como irreversible en Brasil, la marcha política y social contra la esclavitud, que por fin vendría a ser abolida en 1888. Pero había un descompás. El negocio de la caña de azúcar, que por siglos había otorgado la hegemonía económica y política del país a manos de los terratenientes del norte de Brasil, y que tenía el trabajo esclavo como base de su mo- 
do productivo, declinaba sin vuelta atrás. Mientras, en el sur cafeticultor (donde se sitúan provincias como São Paulo y Río de Janeiro) ya se planteaba el trabajo asalariado y esta región se adelantaba en muchos sentidos al resto del país. En líneas generales, el norte abogaba por el mantenimiento del trabajo esclavo, mientras el sur por su abolición. Lo que se preguntaba en todo el país era como quedaría Brasil sin los esclavos, que prácticamente desde la llegada de los portugueses en 1500 estructuraban toda la economía brasileña, sirviendo no solamente de brazo para la agricultura, sino de manos para casa y cocina y pecho para los bebes, entre otras funciones. ¿Y qué harían negros y mulatos a partir de la abolición? ¿Serían capaces los brasileños de origen europeo de, de un momento a otro, pasar a contratar negros y mulatos y pagarles un sueldo en dinero, a ellos que hasta ayer trabajaban sin cobrar? En fin, ¿cómo se estructuraría la nueva sociedad?

La contestación que sugiere El mulato no es nada animadora, o mejor, es realista. Su personaje principal, el mulato Raimundo, bastardo, aunque acabe de volver de Europa, donde estudió y se doctoró, sufre feroz prejuicio por parte de la sociedad de su entorno: la ciudad de São Luis, capital de la norteña provincia de Maranhão (que es también la ciudad del autor Aluísio Azevedo). A la vez, el villano de la trama es un cura lascivo, en una abierta provocación del autor a la institución de la iglesia y, por ende, a la monarquía, que todavía era el sistema de gobierno en Brasil. No está de más recordar que a la causa abolicionista iba casi siempre unida la republicana, anti-monárquica y anti-clerical. Raimundo, el mulato, tiene éxito con las jóvenes mujeres, pero la familia de su amada, perteneciente a la élite conservadora, no permite la relación, hasta el punto de que el mulato es asesinado al final de la novela. La contestación de Azevedo -después de estos comentarios superficiales que acabamos de hacer sobre la obra- nos parece que es no, que no habrá espacio para los mulatos y negros en el nuevo orden social de Brasil. No habrá integración, o por lo menos no habrá una integración fácil y sin conflicto. Esta contestación realista con tintes naturalistas, chocantes para la época por sus descripciones sin medias tintas, desagrada a los receptores de São Luis y de la provincia de Maranhão que, quizás, no querían reconocer la propia sordidez de su sociedad retratada tan sin ceremonia en la obra. El libro y su autor son atacados hasta tal punto que Aluísio Azevedo se ve obligado a mudarse a Río de Janeiro, donde El mulato había sido recibido de otra forma, más exitosa.

En Río, entonces la capital de Brasil, puede que les gustase a los lectores constatar el retraso atroz de los del norte, aunque también en Río el prejuicio hacia negros y mulatos imperase. De todos modos, Río de Janeiro recibió la obra con otros ojos. Supuestamente más cultos y avanzados, los cariocas ${ }^{10}$ halagaron a El mulato como genuino ejemplo de estilo naturalista escrito por un autor brasileño. Y de ahí podemos intuir que en la sociedad brasileña de la época existía otra pregunta, que tenía más que ver con aspectos artísticos y literarios.

${ }^{10}$ Carioca: nacido en Río de Janeiro. 
En este sentido, El mulato surge también contestando a esa expectativa de ver en territorio nacional a un escritor que pudiese llevar a cabo el proyecto naturalista que ya estaba en boga en Europa a manos de autores como el portugués Eça de Queirós o el francés Émile Zola, considerado el padre de este estilo. El mulato contestaba, como mínimo, a estas dos preguntas cuando surgió, una de carácter social, otra acerca del ámbito literario. Otras más profundas y mejor justificadas surgirían sin duda si hubiéramos dedicado a ese breve análisis algo más de tiempo. Pero tenemos que volver a España y a los tiempos actuales.

Está claro que la expectativa de nuestro público en España difiere mucho de la del público original del libro. Está clarísimo que las preguntas de aquella época en Brasil no se aplican a nuestros receptores españoles. Pero nos parece claro también que El mulato seguirá contestando a preguntas, ahora a nuevas preguntas surgidas de las expectativas de nuestros receptores españoles acerca del libro. Imaginemos: un joven recién licenciado está en una librería de Madrid en 2008 y ve El mulato en una estantería. Si se detiene un momento a mirar el libro, su portada, su texto de presentación o la biografía del autor, seguramente le surgirán expectativas acerca del texto que contiene. Imaginemos ahora la misma escena pero en 2012, cuando las noticias que este joven -consumidor frecuente de los medios de comunicación impresos, electrónicos y digitalestiene de Brasil ya son más numerosas que en 2008, principalmente cuando el tema es economía. Aquí llegamos a una de las claves de lo que nos interesa saber dentro de nuestra línea de razonamiento en este estudio: ¿habrá algún cambio de expectativa respecto a El mulato si comparamos el mismo público receptor en los años 2008 y 2012? Ya hemos discurrido, en párrafos anteriores, sobre la pérdida paulatina del carácter exótico consecuente del avance económico. Con eso sabemos que en 2012 la literatura brasileña en general y El mulato en particular parecerían menos exóticos de lo que pudieran parecer en 2008 a los ojos de nuestro público receptor. ${ }^{11} \mathrm{Al}$ comprar la obra en 2012, o al verla en exposición en una librería, el público ya tendría otra expectativa respecto a la que pudiera haber tenido en 2008. Algo ha cambiado, aunque sutilmente. Intentemos avanzar.

Un posible cambio en esta mirada: el receptor de 2008, todavía con poca o ninguna información acerca del avance económico de Brasil, podrá querer buscar en el libro eventuales pistas que le hagan entender mejor cómo fue la formación de la sociedad brasileña, cómo funcionaban las relaciones sociales de sus gentes y, a partir de esto, qué razones llevaron a que esta zona tropical del mundo fracasase económicamente, resultando en un proyecto de nación sin éxito, estancado, retrasado, plagado de pobreza e injusticias sociales. En cambio, el receptor de 2012, ya con mucha más información acerca de la nueva realidad

\footnotetext{
${ }^{11}$ En 2008, cuando se lanza el libro, su propia editorial parece asumir para la obra el concepto de exótico, utilizándolo como argumento de venta. Dice la sinopsis en la contraportada del libro y en la web de la editorial, por ejemplo, que El mulato "consigue un tejido extraño" y que es "una combinación feliz y excéntrica" que utiliza "estrafalarios personajes y todo el color local de sus descripciones".
} 
económica brasileña, puede que busque en el libro respuestas que le den pistas precisamente de lo contrario, es decir, explicaciones acerca de la formación de una sociedad que, al fin y al cabo, parece emerger como potencia económica, subsanando poco a poco sus problemas y caminando hacia el éxito en el panorama global. Como decíamos, trabajamos en el campo de las hipótesis basándonos en sutilezas receptivas. De todos modos, esta alteración de percepción hacia el país suramericano puede que ya sea suficiente para significar un cambio de mirada a su literatura y un consecuente cambio de recepción del libro. La valoración conferida a la obra, por ejemplo, cambiaría en el sentido de que la relación con El mulato sería otra antes y después de 2008. Por relación entendemos la confrontación entre la expectativa creada antes de la lectura y la experiencia vivida durante el proceso de lectura. Este proceso de leer será afectado según la expectativa creada. Si la expectativa es de buscar respuestas al fracaso, la lectura será llevada a cabo de una manera. Si la expectativa, al revés, es buscar respuestas al éxito, la lectura será otra. Por eso, para finalizar nuestro estudio, pasamos ahora a intentar percibir algún detalle precisamente dentro de ese proceso de lectura, y para eso seguiremos apoyándonos en conceptos de las teorías de la recepción y del efecto. Echemos un vistazo, entonces, al fenómeno de los puntos de indeterminación.

El texto impreso en el libro, como ya decíamos, es un esquema a la espera de un lector que venga a ponerlo en marcha. Esta puesta en marcha del esquema es llamada concreción. Lectores de diferentes características y situados en distintas realidades histórico-sociales concretarán de formas distintas un mismo esquema, como, creemos, ya ha quedado claro. El paso del esquema que es el texto impreso a la obra de arte literaria concretada se realiza cuando el receptor empieza a llenar los lugares vacíos, o, dicho de otra manera, a determinar los puntos de indeterminación presentes en el esquema, eliminándolos. Puntos de indeterminación son todos los lugares del texto que se quedan "en abierto". Este proceso de llenar los espacios vacíos no es, la mayoría de las veces, consciente. Al leer, lo que ocurre es que automáticamente vamos llenando muchos puntos indeterminados del texto (al tiempo que muchos otros se quedan abiertos). Sin embargo, llenar los espacios vacíos no es un proceso totalmente libre, ya que el propio texto impone límites a nuestras determinaciones. Es como un juego dirigido, donde tenemos la libertad de añadir piezas, pero siempre dentro de un abanico de posibilidades coherentes.

Con "Era un día sofocante y tedioso" empieza Aluísio de Azevedo El mulato. El acto aparentemente simple e incluso ingenuo de leer esta frase puede hacernos entender mejor cómo llenamos los espacios vacíos de un texto. En todo receptor de literatura de ficción, el simple hecho de mirar a una frase desencadena automáticamente en su consciencia un curioso proceso de creación de imágenes y sensaciones mentales. Actuamos de este modo "en parte por la influencia sugestiva del texto y en parte también por una natural inclinación, porque estamos acostumbrados a considerar las cosas y personas individuales como completamente determinadas" (Roman Ingarden en Warning 1989: 38). Esas 
imágenes y sensaciones estimuladas por el texto varían de acuerdo con la realidad histórico-social del lector. Un día "sofocante" para un lector madrileño, acostumbrado a veranos secos, será distinto de un día "sofocante" para un carioca, acostumbrado a veranos húmedos. La construcción de sentido a partir de la misma frase será distinta para uno y para otro. El texto suministra la información "día sofocante", pero no aclara, por lo menos en este momento, si el ambiente era, por ejemplo, húmedo o seco, nublado o soleado, si eran las doce de la mañana o las seis de la tarde. Estos son los espacios indeterminados a ser determinados por quien recibe la obra y construye su sentido.

El naturalismo suele ser muy descriptivo -cargar los aspectos físicos de esas descripciones es incluso una de sus características-. Pero describir exhaustivamente no contribuye a eliminar lugares de indeterminación dentro de la narrativa. Puede que ocurra más bien lo opuesto: cuanto más se describe, más se fomenta la aparición de puntos indeterminados. De todos modos, no es ese el centro de la cuestión. Lo fundamental, propuesto desde el principio de este artículo, es comentar sobre posibles alteraciones en la recepción de la literatura brasileña en España después de que el país suramericano empezase a ser percibido por el público español destacado por nosotros como potencia económica emergente. Hemos visto al principio algunos números, y nuestro recorrido nos ha hecho llegar hasta aquí, a un grado más profundizado -y teórico- de análisis.

El mulato -edición de 2008 de la Editorial Antonio Machado, con traducción de Juan Sebastián Cárdenas-así empieza:

Era un día sofocante y tedioso. La pobre ciudad de São Luís do Maranhão parecía entumecida por el calor. A duras penas se podía salir a la calle: las piedras escaldaban, los ventanales y faroles al sol eran como enormes diamantes, las paredes tenían reverberaciones de plata pulida, las hojas de los árboles ni se movían, las carrozas de agua pasaban a cada instante estremeciendo las construcciones y los aguadores, en mangas de camisa, con los pantalones remangados, invadían sin ceremonia alguna las casas para llevar bañeras y vasijas. En ciertos puntos no había ni un alma en la calle. Todo estaba concentrado, adormecido. Sólo los negros hacían las compras para la cena o se buscaban la vida. (Azevedo 2008: 17).

Un "día sofocante", como acabamos de alertar, no es igual de sofocante en Madrid que en São Luís do Maranhão o Río de Janeiro (e incluso entre esas dos ciudades brasileñas serían distintas las sensaciones). "Las piedras" que "escaldaban" forman parte de una calle típica de las ciudades brasileñas coloniales, así como los "ventanales" y otras referencias arquitectónicas. "Las hojas de los árboles" que "ni se movían" son hojas nunca vistas en Madrid, pues los árboles de Maranhão son otros. El receptor español construye a su modo tanto las hojas como los árboles, y también las ventanas, las calles o la sensación sofocante. Al construir en su conciencia elementos que el texto ha dejado abiertos, está determinando por su cuenta lo indeterminado. Añadamos además que la concreción llevada a cabo por un brasileño no será mejor que la del español. Recorde- 
mos que estamos tratando de una obra de ficción, y lo que el receptor tiene que representar en su conciencia a partir del texto no depende para su éxito de la relación con algo real, con una ciudad real o con ventanas y calles reales. Serán concreciones distintas, nada más que eso.

Pero, ¿qué puede, en fin, cambiar en esta determinación de los puntos indeterminados cuando comparamos una recepción de un madrileño en 2008 con una de un receptor también madrileño en 2012? Sabemos que la experiencia previa del receptor cuenta mucho en este proceso. Aunque tenga consciencia de estar dentro de una obra de ficción, es del mundo conocido del que él generalmente saca material para concretar un dato indeterminado. Pues bien. Si observamos que en los medios españoles, de los cuales nuestro receptor es espectador frecuente, existe un aumento de noticias dando cuenta del avance económico de Brasil, principalmente a partir de 2008, y si consideramos también que muchas de estas noticias vienen acompañadas de imágenes, es fácil deducir que la escalada de oferta de información general sobre Brasil suministra más posibilidades de construcciones de sentido a nuestros receptores en España. No estamos diciendo, volvemos a repetir, que este lector pasaría a construir mejor el sentido del texto, sino solamente que lo construiría de modo distinto antes y después de la toma de contacto con gran cantidad de textos e imágenes referentes a Brasil.

\section{Conclusión}

Sigue pareciéndonos claro que el cambio de escalón político-económico de Brasil en el panorama global presupone alteraciones en la recepción de su literatura en diversos niveles. En nuestro caso específico, que es la recepción en España, el número de traducciones y lanzamientos parece dibujar una línea crecente, saldando poco a poco el débito que el mercado editorial español -y el de los demás países de habla hispana, aunque vecinos de Brasil- tiene con la literatura en lengua portuguesa (Portugal incluido, según hemos averiguado en otra ocasión); políticas públicas actuales del gobierno brasileño parecen mirar con atención a esa cuestión y empiezan a destinar presupuestos inéditos para llevar a cabo proyectos que fomentan traducciones de obras brasileñas en el exterior $-\mathrm{y}$ destinar mayores presupuestos, creemos, tiene que ver con el buen momento económico del país, sumado claro está a una positiva voluntad política-; por fin, en el nivel más íntimo de la relación entre libro y lector, pensamos percibir cambios, aunque sutiles, en la forma de leer la literatura brasileña, ya sea en lo relacionado a las alteraciones en el horizonte de expectativas o en la manera de determinar los espacios indeterminados del texto. Quedaría ahora continuar observando en los próximos años esas dos líneas que se entrecruzan -la económica y la literaria- para poder, posteriormente, volver a comentar este tema con más distanciamiento temporal. De momento, nos quedamos aquí. 


\section{Referencias bibliográficas}

AZEVEDO, Aluísio (2008). El mulato. Madrid: Antonio Machado Libros.

BosI, Alfredo (1993). Dialética da colonização. São Paulo: Cia. Das Letras. (1994). História concisa da literatura brasileira. São Paulo: Cultrix.

CANDIDO, Antonio; Gomes, Paulo Emílio Sales; PradO, Décio de Almeida; RoSENFELD, Anatol (1968). A personagem de ficção. São Paulo: Perspectiva.

ECO, Umberto (1992). Obra abierta. Barcelona: Planeta de Agostini.

JAUSS, Hans Robert (1986). Experiencia estética y hermenéutica literaria. Madrid: Taurus Ediciones.

(1994). A história da literatura como provocação à ciência literária. São Paulo: Ática.

MAYORAL, José Antonio (ed.) (1987). Estética de la recepción. Madrid: Arco/Libros.

MUKAROWSKY, Jan (1977). Escritos de estética y semiótica del arte. Barcelona: Gustavo Gili.

SCHWARTZ, Jorge (2008). Vanguardas latino-americanas. São Paulo: Editora da Universidade de São Paulo.

WARNING, Rainer (ed.) (1989). Estética de la recepción. Madrid: Visor DL.

WOLFGANG, Iser (1996). O ato da leitura. São Paulo: Editora 34. 